\title{
Effects of Currently Available Surgical and Restorative Interventions on Reducing Midfacial Mucosal Recession of Immediately Placed Single-Tooth Implants: A Systematic Review
}

\author{
Guo-Hao Lin, ${ }^{* \dagger}$ Hsun-Liang Chan, ${ }^{\dagger}$ and Hom-Lay Wang ${ }^{\dagger}$
}

Background: Procedures to improve peri-implant softtissue outcomes of single, immediately placed implants are a topic of interest. This systematic review investigates the effect of various surgical and restorative interventions on implant mid-buccal mucosal level.

Methods: An electronic search of five databases (January 1990 to December 2012) and a manual search of peerreviewed journals for relevant articles were performed. Randomized controlled clinical trials (RCTs), prospective cohort studies, and case series with at least nine participants were included, with data on midfacial mucosal recession (MR) of immediately placed implants following various surgical and restorative interventions with a follow-up period of at least 6 months.

Results: Thirty-six studies, eight RCTs, one cohort study, and 27 case series were eligible. Six interventions were identified and reviewed: 1) palatal/lingual implant position; 2) platform-switched abutments; 3) flapless approach; 4) bone grafts to fill the gap between buccal plate and fixture; 5 ) connective tissue grafts; and 6) immediate provisionalization. Three studies consistently showed that palatally/lingually positioned implants had significantly less MR when using tissue-level implants. Mixed results were reported for interventions $2,3,5$, and 6 . One study was available for intervention 4 and did not show a benefit.

Conclusions: Some interventions might be adopted to reduce the amount of MR on implants with the immediate placement approach, as suggested by the included studies, with various levels of evidence. The conflicting results among studies might be a result of differences in patient and site characteristics, e.g., tissue biotype and buccal plate thickness. Therefore, the use of these interventions might be reserved for patients with moderate to high risk of esthetic complications. J Periodontol 2014;85:92-102.

\section{KEY WORDS}

Dental implantation; dental implants; esthetics; gingival recession; peri-implantitis; review, systematic.

\footnotetext{
* Department of Stomatology, Taipei Veterans General Hospital, Taipei, Taiwan.

$\dagger$ Private Practice, Hsinchu, Taiwan.

$\neq$ Graduate Periodontics, Department of Periodontics and Oral Medicine, University of Michigan School of Dentistry, Ann Arbor, MI.
}

I mmediate implant placement (IIP) is defined as a procedure in which "an implant is placed following tooth extraction in the same surgical procedure." 1 The compelling reason for the popularity of IIP is the patient's desire for faster dental rehabilitation. Numerous clinical trials ${ }^{2-8}$ have proved the predictability of this approach, with the survival rate similar to that of the conventional approach, assuming prudent case selection and treatment planning. Some important anatomic factors related to the success of IIP should be assessed, including implant location,, 10 gingival marginal position, 2,3,11,12 interdental papilla height, ${ }^{4-6,12}$ width and thickness of keratinized mucosa, ${ }^{3,7,13}$ gingival biotypes, ${ }^{2,3,11,14,15}$ crestal bone level, ${ }^{16,17}$ position of implant platform, ${ }^{18}$ thickness of buccal bone wall, ${ }^{9,10}$ dimension of the horizontal buccal gap, $, 9,10$ and sagittal root position. ${ }^{19}$ Careful evaluation of these factors can avoid most complications associated with IIP.

Nonetheless, untoward outcomes do happen following IIP procedures. The most commonly reported complications include dehiscence of the wound and exposure of membranes related to the guided bone regeneration procedure, ${ }^{20}$ inevitable ridge resorption, ${ }^{21,22}$ midfacial mucosal recession (MR), ${ }^{2,3,8}$ loss of interdental papilla, ${ }^{6,11,23,24}$ and

doi: 10.1902/jop.2013.130064 
a color change of peri-implant soft tissue from improper abutment material selection. ${ }^{25}$ Of these complications, MR has received attention recently ${ }^{20,26}$ because it occurs relatively frequently and results in an unpleasing esthetic outcome.

To avoid advanced MR, various surgical and restorative protocols for IIP have been proposed and tested. ${ }^{5,27-30}$ For example, a flapless approach might be better for preserving soft-tissue architecture than a flap approach. ${ }^{31}$ Limited evidence has shown that immediately restoring an immediately placed implant could maintain the level of mucosal margin. ${ }^{5,32}$ However, there is a lack of reviews that critically investigate the benefit of applying currently available surgical and restorative interventions on facial mucosal level. Therefore, the aim of this systematic review is to evaluate the amount of MR for each of the available procedure modifications, in comparison to controls.

\section{MATERIALS AND METHODS}

\section{Focused Question}

The focused question addressed is: "What is the effect of each of the available surgical and restorative interventions on MR of immediately placed single implants?"

\section{Search Strategy}

A search of five electronic databases, including PubMed, Ovid (MEDLINE), EMBASE, Web of Science, and Cochrane Central, was performed for relevant studies published in the English language from January 1990 until December 2012. The search terms used were: 〈"immediate implant"[tiab] OR "immediate implant placement" [tiab] OR "immediate implant installation"[tiab] OR "early implant placement"[tiab] OR "immediate restoration"[tiab] OR "immediate provisionalization" [tiab] OR \{("dental implants"[mh] OR "dental implantation"[mh] OR "implants"[tiab]) AND ("extraction"[tiab] OR "immediate"[tiab] OR "immediately"[tiab])\} AND ("recession"[tiab]OR "esthetic"[tiab] OR "aesthetic"[tiab] OR "esthetics, dental" [mh]) $\rangle$, where mh represents $\mathrm{MeSH}$ terms and tiab represents title and/or abstract.

A manual search was also carried out in dental and implant-related journals from January 2000 until December 2012, including Journal of Periodontology, Clinical Implant Dentistry and Related Research, International Journal of Oral and Maxillofacial Implants, Clinical Oral Implants Research, Implant Dentistry, International Journal of Oral and Maxillofacial Surgery, Journal of Oral and Maxillofacial Surgery, Journal of Dental Research, Journal of Prosthetic Dentistry, International Journal of Prosthodontics, Journal of Oral Implantology, Journal of Clinical Periodontology, and International
Journal of Periodontics \& Restorative Dentistry. The European Journal of Oral Implantology was searched from January 2008 until December 2012. Furthermore, a search in the references of included papers was conducted for publications that were not electronically identified. The search strategy was performed by one examiner (GL).

The included publications had to fulfill all the following criteria: 1) randomized controlled clinical trial (RCT), prospective cohort study, or case series; 2) at least nine participants; 3) studied implants located in the anterior or premolar region, with presence of adjacent teeth; 4) implants placed immediately using at least one surgical or restorative modification; 5) follow-up period of at least 6 months after restoration; and 6) midfacial MR reported as an outcome variable.

Reviews and case reports were excluded, but their bibliographies were screened for potential articles to be incorporated. Correspondence authors of potentially included papers were contacted for clarification of study methods or more detailed data sets. Potential articles were examined in full text by two reviewers (GL and $\mathrm{HC}$ ), and their eligibility for this review was confirmed after discussion. The level of agreement between the reviewers regarding study inclusion was calculated using $\kappa$ statistics.

\section{Risk of Bias Assessment}

The criteria used to assess the quality of the selected RCTs were modified from the randomized clinical trial checklist of the Cochrane Center ${ }^{33}$ and the CONSORT statement, ${ }^{34}$ which provided guidelines for the following parameters: 1) representative of general population; 2) defined inclusions/exclusions; 3) randomization methods; 4) allocation concealment method; 5) masking of the examiner; 6) intervention different only; 7) participant dropout; and 8) analysis accounting for patient losses (Table 1). Degrees of bias were categorized as low risk if all criteria were met, moderate risk when only one criterion was missing, and high risk if two or more criteria were missing. Meanwhile, the included cohort study was assessed using the Newcastle-Ottawa scale. ${ }^{35}$ Each cohort study was evaluated and rated from a maximum of nine stars to a minimum of zero stars. Any study scored less than five stars was excluded. Two reviewers (GL and $\mathrm{HC}$ ) assessed all the included articles independently.

\section{Data Extraction}

Data were extracted by two observers (GL and HC) independently from the included papers that met the criteria and were processed for analysis. If any disagreement was found, an agreement was accomplished with discussion. The parameters 


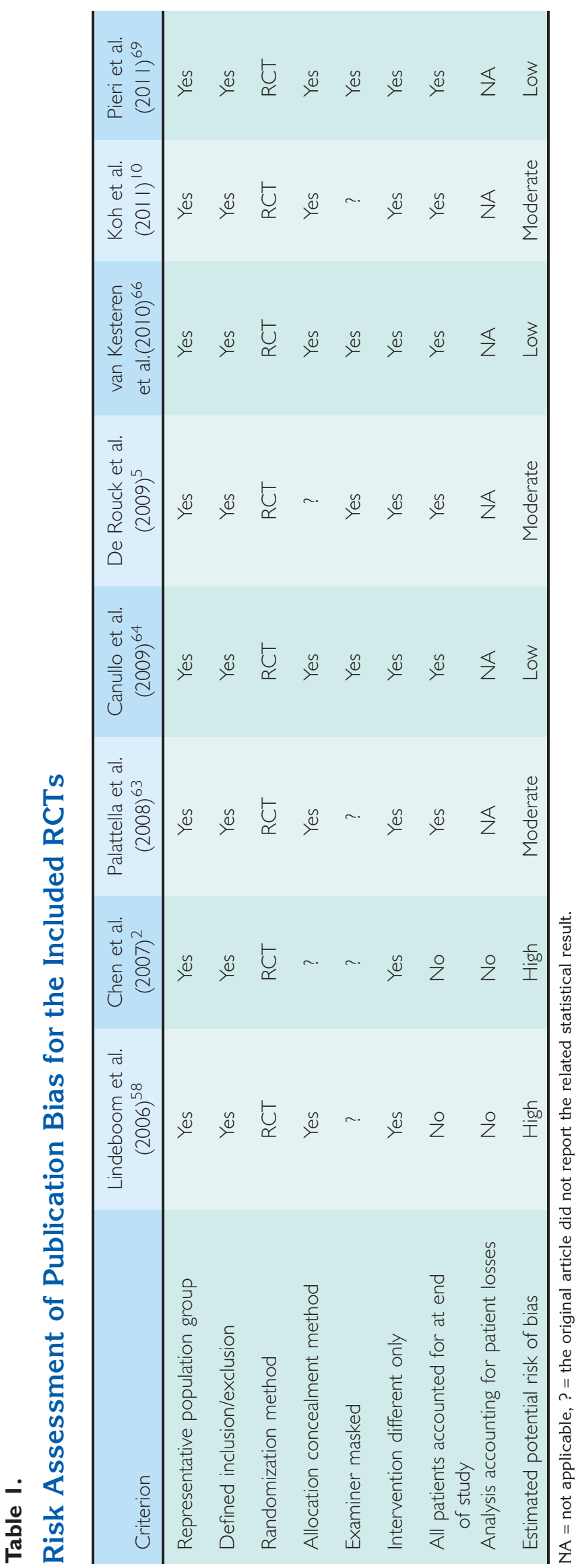

recorded for each study included: 1) authors' names; 2) year of publication; 3) study design; 4) sample size; 5) demographic information of the participants; 6) number of fixture placements; 7) locations of implants; and 8) follow-up period. Interventions that were available for the analysis included: 1) palatal implant position; 2) platformswitched (PS) design; 3) flapless approach; 4) use of bone grafting materials to fill the horizontal gap between implant and facial plate; 5) addition of connective tissue grafts (CTGs); and 6) immediate fixed provisionalization.

\section{Data Analyses}

The outcome was the difference in the mean MR between each intervention and its control; no comparison among interventions was intended. Due to limited sample size from only including comparative studies, publications without a control group were also included to evaluate the mean MR of each procedure modification. Considerable heterogeneities among studies, in particular study designs, various interventions, and small sample size for each procedure category, precluded a meaningful meta-analysis; therefore, the results are presented narratively. The data presented in this systematic review adhere to the PRISMA (Preferred Reporting Items for Systematic Review and MetaAnalyses) statement. ${ }^{36}$

\section{RESULTS}

The screening process is shown in Figure 1 . Electronic and hand searches yielded 617 articles, of which 55 were selected for full-text evaluation after screening their titles and abstracts. Nineteen articles were further excluded $9,16,21,37-52$ (reasons for exclusion are listed in Table 2). Thirty-six articles $^{2-8,10,11,13,23,24,30-32,53-73 ~ w e r e ~ i n c l u d e d ~ i n ~ t h i s ~}$ systematic review. The main features and conclusions of the included studies are summarized in Supplementary Table 1 in the online Journal of Periodontology.

The $\kappa$ value for interreviewer agreement for potentially relevant articles was 1 (titles and abstracts) and 0.95 (full-text articles), indicating an almost perfect agreement between the two reviewers, according to the criteria by Landis and Koch. ${ }^{74}$

\section{Features of the Included Studies}

Study design and participant features. Eight RCTs, ${ }^{2,5,10,58,63,64,66,69}$ one cohort study, ${ }^{4}$ and 27 case series ${ }^{3,6-8,11,13,23,24,30-32,53-57,59-62,65,67,68,70-73 ~}$ were included. One study by Kan et al. ${ }^{7}$ is a longterm follow-up report of another study, ${ }^{6}$ and both studies used the same surgical/restorative techniques and shared the same study population. Similarly, another case series ${ }^{68}$ is a follow-up report 


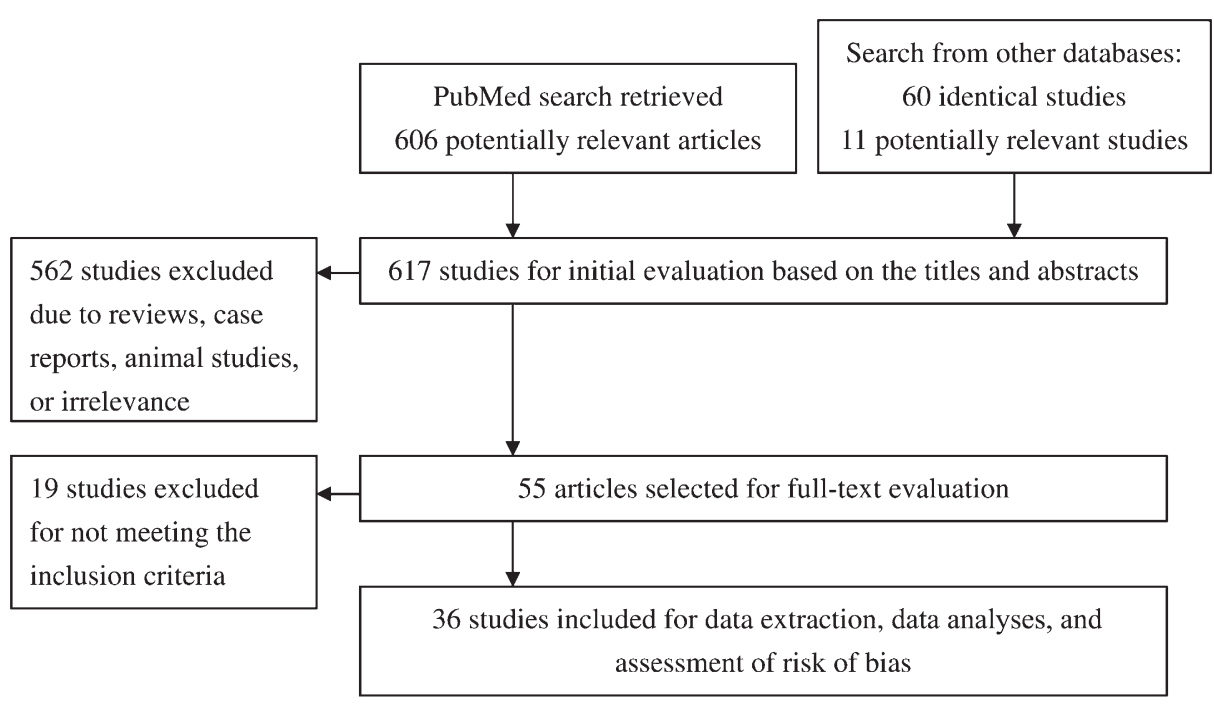

Figure I.

Publication selection process.

placed palatally than buccally (in Chen et al., ${ }^{2} 16.67 \%$ versus 58.33\%; in Evans and Chen, ${ }^{11}$ $28.13 \%$ versus $80 \%$ ). One study $^{3}$ also showed significantly less mean marginallevel change from the baseline around palatally positioned $(2.6 \%)$ than buccally positioned (6.9\%) implants. It should be noted that in the three studies with statistical analyses, ${ }^{2,3,11}$ tissue-level implants were used; the diameter of such implants at their platform is wider than that of the implant body. In addition, tissue-level implants cannot be placed as deeply as bone-level implants. Both features make an esthetic outcome more

of the cohort study. ${ }^{4}$ Of the included studies, the age of the participants ranged from $18^{6,61}$ to $84^{73}$ years. Smoking was not an exclusion criterion in most studies.

Extraction site. All fixtures were placed in either anterior or premolar regions of the maxilla or mandible. Sockets with considerable loss of labial/ buccal bone wall were excluded in all but five studies. $^{2,8,24,61,72}$ Of these five studies, one ${ }^{2}$ included four dehiscence sites ranging in height from 6 to $10 \mathrm{~mm}$; two studies did not specify the height of dehiscence, but grafting materials were used to treat the sites; ${ }^{24,61}$ one study ${ }^{8}$ included sites with facial osseous defects $>3 \mathrm{~mm}$ subsequently treated with guided bone regeneration; and one study ${ }^{72}$ included 3-wall defects if the dehiscence did not exceed $3 \mathrm{~mm}$. Demographic information of the implants included in this review is listed in Supplementary Table 1 in the online Journal of Periodontology.

\section{Interventions and Their Effects on MR}

1) Implant position. Statistical results of the effects of the six interventions on MR are summarized in Table 3. Three studies ${ }^{2,3,11}$ clearly defined implants as being "buccally positioned" when: 1) the distance between buccal bone wall and healing cap was $\leq 2 \mathrm{~mm} ;{ }^{2}$ or 2 ) the buccal edge of the implant shoulder was at or buccal to a reference line drawn between the cervical buccal position of the adjacent teeth following the line of the arch. ${ }^{3,11}$ Three studies $^{4,54,68}$ stated in the text that implants were placed in a more palatal/lingual position but without further information. There were significantly fewer cases having $M R>1 \mathrm{~mm}$ when the implants were difficult to achieve with tissue-level implants.

2) PS design. Six studies $23,59,64,67,69,70$ used implants with the PS design, of which two were RCTs. ${ }^{64,69}$ One study ${ }^{64}$ showed a mean (SD) mucosal level gain of $0.18(0.46) \mathrm{mm}$ in the PS group, compared with a loss of $0.45(0.27) \mathrm{mm}$ in the conventional connection group; the mean difference was significant $(P<0.005)$. However, another $\mathrm{RCT}^{69}$ failed to demonstrate a beneficial effect of the PS design on the mucosal level. The other four studies $^{23,59,67,70}$ were case series, reporting a favorable outcome using PS implants, with the mucosal margin ranging from a loss of $0.2 \mathrm{~mm}$ to a gain of $0.2 \mathrm{~mm}$.

3) Flapless approach. In 15 studies, ${ }^{3,6,7,10,13,23,53-55,57,59,60,64,65,71}$ a flapless approach was adopted exclusively and showed an overall stable soft-tissue level. In four studies, $, 8,24,31,32$ a flapless approach was used in some participants, of which three studies $8,24,31$ allowed for comparisons of MR between the flapless and flap groups as results of secondary data analyses. Only one study ${ }^{31}$ showed significantly less recession in the flapless group (mean difference $0.89 \mathrm{~mm} ; P=$ 0.023); the other two studies failed to support the use of the flapless approach for better mucosal level.

4) Bone grafts. Bone grafting materials were used in 19 studies, 2,4,5,8,10,23,30,53,54,59,61,64-69,72,73 including autogenous bone grafts, ${ }^{53,54}$ allografts, ${ }^{10}$ mixed xenogeneic and autogenous bone grafts, ${ }^{69}$ and xenografts. $2,4,5,8,23,30,59,61,64-68,72,73$ Criteria for use of bone grafts were gaps of $>0 \mathrm{~mm},{ }^{4,68}>1$ $\mathrm{mm},{ }^{54,59,64}$ or $>2 \mathrm{~mm} \cdot{ }^{61,66,73}$ Other studies did not specify the indications. Only one study ${ }^{64}$ 
Table 2.

\section{Summary of the Excluded Articles}

\begin{tabular}{|c|c|}
\hline Reason for Exclusion & Study \\
\hline No data of soft-tissue levels & $\begin{array}{l}\text { Chaushu et al. }(2001)^{37} \\
\text { Hui et al. }(200 \text { I })^{38} \\
\text { Nemcovsky et al. }(2002)^{39} \\
\text { Covani et al. }(2003)^{40} \\
\text { Botticelli et al. }(2004)^{21} \\
\text { Norton }(2004)^{42} \\
\text { Sclar (2004) } \\
\text { Vanden Bogaerde et al. } \\
\quad(2005)^{44} \\
\text { Kupershmidt et al. }(2007)^{16} \\
\text { Romeo et al. }(2008)^{47} \\
\text { Ferrus et al. }(2010)^{9} \\
\text { Valentini et al. }(2010)^{50} \\
\text { Suito et al. }(2011)^{51} \\
\text { Spinato et al. }(2012)^{52}\end{array}$ \\
\hline Molar regions included & $\begin{array}{l}\text { Bianchi and Sanfilippo } \\
(2004)^{41} \\
\text { Galli et al. }(2008)^{46}\end{array}$ \\
\hline $\begin{array}{l}\text { No investigated intervention } \\
\text { introduced }\end{array}$ & $\begin{array}{l}\text { Capelli et al. }(2010)^{49} \\
\text { Botticelli et al. }(2008)^{45} \\
\text { Cordaro et al. }(2009)^{48}\end{array}$ \\
\hline
\end{tabular}

evaluated the effect of bone grafts on recession as a secondary outcome; it failed to show that the addition of bone grafts could reduce recession.

5) CTGs. Eleven included studies applied CTGs for the IIP surgery. 3,8,30,60-62,65,67,70,72,73 Most studies did not include a control group, rendering them impossible to assess for the effect of CTGs on improving mucosal level. However, four studies $30,67,70,72$ showed coronal movement of the mucosal level after placing CTGs (if cases with graft necrosis were excluded), ranging from 0.7 to 1.7 $\mathrm{mm}$. Another study ${ }^{60}$ showed a $2.8-\mathrm{mm}$ increase in keratinized mucosa width, which might be explained by coronal repositioning of the mucosal margin. Other studies ${ }^{62,65,73}$ showed minimal recession. Two studies ${ }^{3,8}$ provided comparisons of mucosal level between implants with and without receiving CTGs. One ${ }^{8}$ did not find a benefit of CTGs in significantly reducing the percentage of cases with $>1.5-\mathrm{mm}$ recession $(45.5 \%$ and $25 \%$ for the CTG and control groups, respectively). The other study ${ }^{3}$ showed a marginal effect of preventing recession $(P=0.096)$, with $3.4 \%$ recession in the CTG group, measured from the baseline, and $5.6 \%$ for the same measurement in the control group.
6) Provisionalization. In 26 included papers, ${ }^{4}$ 8,13,23,24,30-32,54,56-59,62-65,67-71,73 the implants were immediately restored with fixed temporary crowns as a part of the IIP procedure; two studies ${ }^{3,11}$ restored the implants immediately with removable prostheses. Two studies ${ }^{5,32}$ evaluated the effect of immediately placed fixed restorations on marginal level as the primary outcome and found significantly less recession, by 0.75 to $1 \mathrm{~mm}$. Another study ${ }^{3}$ did a secondary data analysis and found that removable partial dentures did not significantly reduce recession.

\section{Risk of Bias Assessment}

The results of risk of bias assessment for RCTs are summarized in Table 1. Of the eight included RCTs, two ${ }^{2,58}$ and three ${ }^{5,10,63}$ were considered to have high and moderate risk of bias, respectively. The other three studies ${ }^{64,66,69}$ were considered to have a low risk of bias. Only one cohort study ${ }^{4}$ was included that scored 7 of 9 stars according to the Newcastle-Ottawa scale, ${ }^{35}$ and therefore was determined to have a moderate risk of bias.

\section{DISCUSSION}

IIP might be associated with a higher incidence of $M R^{20}$ and subsequent poor esthetic appearance, especially for sites with thin soft tissues or wide bony defects on the buccal plate. ${ }^{20}$ The underlying mechanism is not fully understood. It is possible that normal socket healing is exacerbated by additional surgical trauma introduced by placing an implant immediately. ${ }^{75}$ Additionally, the behavior of buccal plate remodeling is highly unpredictable. It is much more difficult to determine vertical implant level in relation to the alveolar crest in IIP than in late implant placement cases. Finally, there is a tendency for surgical drills and implants to shift to the buccal side, thus increasing the risk of MR. ${ }^{76}$ For patients with a high risk for $M R$, a delayed approach might be preferred. There are cases where IIP might be indicated, and at the same time, a moderate esthetic risk might be encountered. Therefore, possible procedures, including placing implants in a more palatal/lingual position, using platform-switched implants, introducing the flapless approach, using bone grafting materials to fill the horizontal gap between implant and facial plate, adding CTGs, and fabricating immediate fixed provisionalization, should be executed to minimize the amount of MR.

This study identified six surgical and restorative modifications for reducing MR, of which only palatal/ lingual implant position consistently showed positive results. Buccally positioned implants led to resorption of the buccal plate and MR when tissue-level 


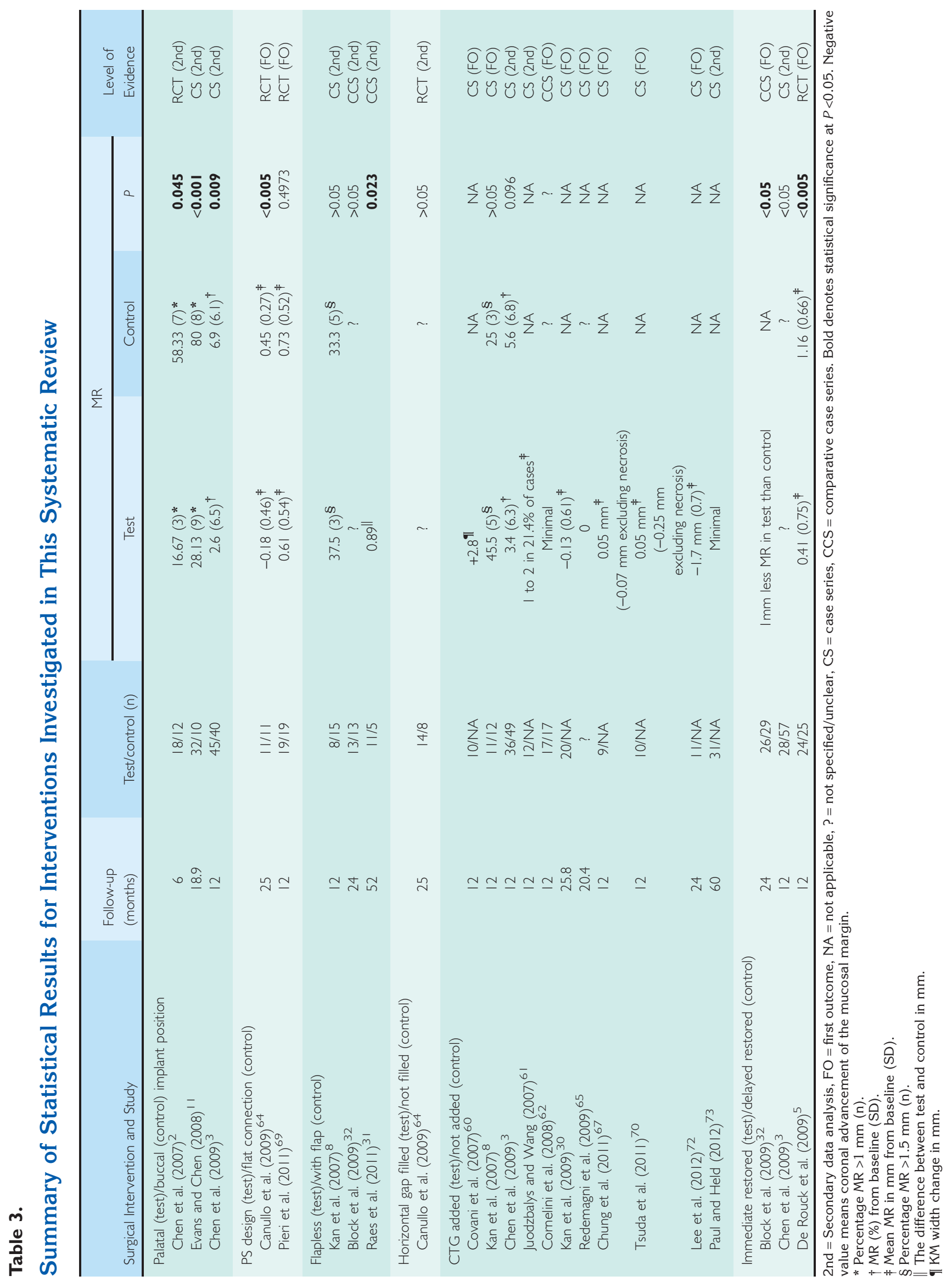


implants were introduced. $2,3,11$ Therefore, surgical guides are recommended for IIP surgeries to prevent buccal shift of the implant position. For esthetically challenging cases, planning an implant at the cingulum position might be beneficial. Additionally, it might be advantageous to select a slightly undersized implant so that more soft- and hard-tissue volume can be preserved on the buccal side. ${ }^{14}$ Information regarding the two approaches above is scarce, and their potential advantages on soft-tissue level are yet to be confirmed.

The use of CTGs has been studied to some extent and is promising; however, because all involved studies are case series, ${ }^{3,8,30,60-62,65,67,70,72,73}$ a firm conclusion could not be made at this time. Of these case series, three ${ }^{30,60,72}$ demonstrated soft-tissuelevel gain when performing IIP with CTG placement simultaneously. There is evidence that the addition of CTGs in IIP successfully converts the tissue biotype. $^{23,28,30,77}$ However, two included studies ${ }^{3,8}$ with statistical analyses failed to support the use of CTGs for reducing MR. The occurrence of surgical complications might have diminished a positive effect. Graft necrosis has been reported to occur in approximately $20 \%$ of treated cases. 67,70

The number of studies $3,5,8,31,32,64,69$ evaluating the other four modifications is limited, and most of the results are conflicting. The PS design showed some positive effects on preserving peri-implant marginal bone. ${ }^{78}$ It is not clear whether the mucosal level could also be preserved with this specific abutment design. Divergent outcomes ${ }^{64,69}$ were reported from this systematic review. The discrepancy might result from potentially confounding factors, e.g., differences of follow-up period, implant position, and soft-/hard-tissue quality/quantity, etc.

The flapless approach, being less invasive and less traumatic to vascular circulation, should be a treatment option for reducing MR. Nevertheless, of the three studies $8,31,32$ addressing this issue, only one $^{31}$ showed a significantly smaller recession with the flapless group (mean difference: $0.89 \mathrm{~mm} ; P=$ 0.023 ). Animal studies also showed conflicting results, reporting that the use of flapless techniques could be beneficial ${ }^{79}$ or futile. ${ }^{80}$ Therefore, the decision on the flap design might be determined by patient comfort, the need for access and ridge augmentation, and the experience level of the surgeon.

Use of bone grafting materials alters the modeling process of the buccal plate after tooth extraction. ${ }^{81}$ Socket augmentation with various types of bone grafts changes the bone quality ${ }^{82}$ and reduces the amount of ridge resorption. ${ }^{83}$ The effect of bone grafts on soft-tissue alterations is not often studied. Only one study ${ }^{64}$ was identified in the current review, which did not show the addition of bone grafts as having a positive effect on reducing MR. Future studies should concentrate on factors that might influence the outcome, e.g., tissue biotype, size of the gap between implant and buccal plate, $, 70,61$ buccal plate thickness, ${ }^{9}$ and type of bone graft.

Fixed immediate restorations may reduce MR by 0.75 to $1 \mathrm{~mm}$, as suggested by the two included studies. ${ }^{5,32}$ Temporary restorations might guide and shape peri-implant soft tissues in the esthetic zone. ${ }^{84}$ Removable appliances may not exert the same benefit for soft-tissue levels. ${ }^{3}$ Long-term follow-up is required to confirm the short-term positive results.

Other restorative modifications to reduce MR and to enhance esthetics include the use of concave or zirconia abutments. Rompen et al. ${ }^{85}$ suggested that the use of concave implant abutments could have more predictable soft-tissue stability in esthetic zones than convex abutments, and a vertical gain of soft-tissue level was observed in $53.7 \%$ of cases. This finding is in accordance with those of $\mathrm{Su}$ et al. ${ }^{86}$ and Redemagni et al. ${ }^{65}$ The metal hue could be avoided by use of a zirconia abutment, especially for patients with thin tissue biotype. ${ }^{87-90}$ Zirconia also showed excellent properties for attachment of epithelial cells and fibroblasts, which might contribute to long-term stability of soft-tissue level. ${ }^{91}$

Limitations of this review are the potential language bias; the number of included studies in each treatment category; overall short follow-up period of the included papers; only midfacial recession investigated; and large variations in the study designs, features of the study sites, interventions, and methods to report soft-tissue level changes among publications. To further explore this complex topic with highly clinical significance, multiple variable regression analyses might be required.

\section{CONCLUSIONS}

Risk assessment is the first step to avoid advanced MR for IIP therapy. Modifications of standard surgical and restorative procedures might be required to maximize the esthetic outcome. Six modifications have been identified from the included 36 studies. Palatal implant position is associated with less MR when using tissue-level implants. Limited evidence suggested that the PS abutment design, flapless approach, addition of CTG, and immediate fixed provisionalization might result in more favorable soft-tissue marginal level, although conflicting reports do exist. Patient and surgical site-related features might account for the inconsistent results 
among publications. Therefore, the application of these modifications should be on a case-by-case basis.

\section{ACKNOWLEDGMENTS}

The authors acknowledge Mark MacEachern, a liaison services librarian in the A. Alfred Taubman Health Sciences Library, University of Michigan, Ann Arbor, MI, for providing consultations on literature search. The authors do not have any financial interests, either directly or indirectly, in the products or information listed in the paper. This paper was partially supported by the University of Michigan Periodontal Graduate Student Research Fund. The authors report no conflicts of interest related to this study.

\section{REFERENCES}

1. Hämmerle $\mathrm{CH}$, Chen ST, Wilson TG Jr. Consensus statements and recommended clinical procedures regarding the placement of implants in extraction sockets. Int J Oral Maxillofac Implants 2004;19 (Suppl.):26-28.

2. Chen ST, Darby IB, Reynolds EC. A prospective clinical study of non-submerged immediate implants: Clinical outcomes and esthetic results. Clin Oral Implants Res 2007; 18:552-562.

3. Chen ST, Darby IB, Reynolds EC, Clement JG. Immediate implant placement postextraction without flap elevation. J Periodontol 2009;80:163-172.

4. De Rouck T, Collys K, Cosyn J. Immediate single-tooth implants in the anterior maxilla: A 1-year case cohort study on hard and soft tissue response. $J$ Clin Periodontol 2008;35:649-657.

5. De Rouck T, Collys K, Wyn I, Cosyn J. Instant provisionalization of immediate single-tooth implants is essential to optimize esthetic treatment outcome. Clin Oral Implants Res 2009;20:566-570.

6. Kan JY, Rungcharassaeng K, Lozada J. Immediate placement and provisionalization of maxillary anterior single implants: 1 -year prospective study. Int $J$ Oral Maxillofac Implants 2003;18:31-39.

7. Kan JY, Rungcharassaeng K, Lozada JL, Zimmerman G. Facial gingival tissue stability following immediate placement and provisionalization of maxillary anterior single implants: A 2- to 8-year follow-up. Int J Oral Maxillofac Implants 2011;26:179-187.

8. Kan JY, Rungcharassaeng K, Sclar A, Lozada JL. Effects of the facial osseous defect morphology on gingival dynamics after immediate tooth replacement and guided bone regeneration: 1-year results. $J$ Oral Maxillofac Surg 2007; 65(7, Suppl. 1):13-19.

9. Ferrus J, Cecchinato D, Pjetursson EB, Lang NP, Sanz $M$, Lindhe J. Factors influencing ridge alterations following immediate implant placement into extraction sockets. Clin Oral Implants Res 2010;21:22-29.

10. Koh RU, Oh TJ, Rudek I, et al. Hard and soft tissue changes after crestal and subcrestal immediate implant placement. J Periodontol 2011;82:1112-1120.

11. Evans CD, Chen ST. Esthetic outcomes of immediate implant placements. Clin Oral Implants Res 2008;19: 73-80.
12. Seibert J, Lindhe J. Esthetics and periodontal therapy. In: Lindhe J, ed. Textbook of Clinical Periodontology, 2nd edition. Copenhagen: Munksgaard; 1989:477514.

13. Crespi R, Capparè P, Gherlone E. A 4-year evaluation of the peri-implant parameters of immediately loaded implants placed in fresh extraction sockets. J Periodontol 2010;81:1629-1634.

14. $\mathrm{Fu} \mathrm{JH}$, Lee A, Wang HL. Influence of tissue biotype on implant esthetics. Int J Oral Maxillofac Implants 2011; 26:499-508.

15. Kan JY, Rungcharassaeng K, Umezu K, Kois JC. Dimensions of peri-implant mucosa: An evaluation of maxillary anterior single implants in humans. $J$ Periodontol 2003;74:557-562.

16. Kupershmidt I, Levin L, Schwartz-Arad D. Inter-implant bone height changes in anterior maxillary immediate and non-immediate adjacent dental implants. J Periodontol 2007;78:991-996.

17. Levin L, Pathael S, Dolev E, Schwartz-Arad D. Aesthetic versus surgical success of single dental implants: 1- to 9-year follow-up. Pract Proced Aesthet Dent 2005; 17:533-538; quiz 540, 566.

18. Tomasi C, Sanz M, Cecchinato D, et al. Bone dimensional variations at implants placed in fresh extraction sockets: A multilevel multivariate analysis. Clin Oral Implants Res 2010;21:30-36.

19. Kan JY, Roe P, Rungcharassaeng K, et al. Classification of sagittal root position in relation to the anterior maxillary osseous housing for immediate implant placement: A cone beam computed tomography study. Int J Oral Maxillofac Implants 2011;26:873-876.

20. Chen ST, Buser D. Clinical and esthetic outcomes of implants placed in postextraction sites. Int $J$ Oral Maxillofac Implants 2009;24 (Suppl.):186-217.

21. Botticelli D, Berglundh T, Lindhe J. Hard-tissue alterations following immediate implant placement in extraction sites. J Clin Periodontol 2004;31:820-828.

22. Covani U, Cornelini R, Barone A. Vertical crestal bone changes around implants placed into fresh extraction sockets. J Periodontol 2007;78:810-815.

23. Cosyn J, De Bruyn H, Cleymaet R. Soft tissue preservation and pink aesthetics around single immediate implant restorations: A 1 -year prospective study [published online ahead of print February 29, 2012]. Clin Implant Dent Relat Res doi:10.1111/j.17088208.2012.00448.x.

24. Raes F, Cosyn J, De Bruyn H. Clinical, aesthetic, and patient-related outcome of immediately loaded single implants in the anterior maxilla: A prospective study in extraction sockets, healed ridges, and grafted sites [published online ahead of print January 17, 2012]. Clin Implant Dent Relat Res doi:10.1111/j.17088208.2011.00438.x.

25. Bressan E, Paniz G, Lops D, Corazza B, Romeo E, Favero G. Influence of abutment material on the gingival color of implant-supported all-ceramic restorations: A prospective multicenter study. Clin Oral Implants Res 2011;22:631-637.

26. Cosyn J, Hooghe N, De Bruyn H. A systematic review on the frequency of advanced recession following single immediate implant treatment. J Clin Periodontol 2012;39:582-589.

27. Cosyn J, Raes S, De Meyer S, et al. An analysis of the decision-making process for single implant treatment in general practice. J Clin Periodontol 2012;39:166172. 
28. Hsu YT, Shieh CH, Wang HL. Using soft tissue graft to prevent mid-facial mucosal recession following immediate implant placement. J Int Acad Periodontol 2012; 14:76-82.

29. Kan JY, Rungcharassaeng K. Immediate placement and provisionalization of maxillary anterior single implants: A surgical and prosthodontic rationale. Pract Periodontics Aesthet Dent 2000;12:817-824, quiz 826.

30. Kan JY, Rungcharassaeng K, Morimoto T, Lozada J. Facial gingival tissue stability after connective tissue graft with single immediate tooth replacement in the esthetic zone: Consecutive case report. J Oral Maxillofac Surg 2009;67(Suppl. 11):40-48.

31. Raes F, Cosyn J, Crommelinck E, Coessens P, De Bruyn H. Immediate and conventional single implant treatment in the anterior maxilla: 1-year results of a case series on hard and soft tissue response and aesthetics. J Clin Periodontol 2011;38:385-394.

32. Block MS, Mercante DE, Lirette D, Mohamed W, Ryser $M$, Castellon P. Prospective evaluation of immediate and delayed provisional single tooth restorations. $J$ Oral Maxillofac Surg 2009;67(Suppl. 11):89-107.

33. Higgins JP, Green S. Cochrane Handbook for Systematic Reviews of Interventions. Version 5.1.0 (updated March 2011). The Cochrane Collaboration, 2011. Available at: http://www.cochrane-handbook.org. Accessed January 9, 2013.

34. Schulz KF, Altman DG, Moher D; CONSORT Group. CONSORT 2010 statement: Updated guidelines for reporting parallel group randomized trials. Ann Intern Med 2010;152:726-732.

35. Department of Epidemiology and Community Medicine, University of Ottawa, Canada. The NewcastleOttawa Scale (NOS) for assessing the quality of nonrandomized studies in meta-analyses. Available at: http://www.ohri.ca/programs/clinical_epidemiology/ oxford.htm. Accessed January 9, 2013.

36. Liberati A, Altman DG, Tetzlaff J, et al. The PRISMA statement for reporting systematic reviews and metaanalyses of studies that evaluate health care interventions: Explanation and elaboration. Ann Intern Med 2009;151:W65-W94.

37. Chaushu G, Chaushu S, Tzohar A, Dayan D. Immediate loading of single-tooth implants: Immediate versus non-immediate implantation. A clinical report. Int $J$ Oral Maxillofac Implants 2001;16:267-272.

38. Hui E, Chow J, Li D, Liu J, Wat P, Law H. Immediate provisional for single-tooth implant replacement with Brånemark system: Preliminary report. Clin Implant Dent Relat Res 2001;3:79-86.

39. Nemcovsky CE, Artzi Z, Moses O, Gelernter I. Healing of marginal defects at implants placed in fresh extraction sockets or after 4-6 weeks of healing. A comparative study. Clin Oral Implants Res 2002;13:410-419.

40. Covani U, Cornelini R, Barone A. Bucco-lingual bone remodeling around implants placed into immediate extraction sockets: A case series. J Periodontol 2003; 74:268-273.

41. Bianchi AE, Sanfilippo F. Single-tooth replacement by immediate implant and connective tissue graft: A 1-9year clinical evaluation. Clin Oral Implants Res 2004; 15:269-277.

42. Norton MR. A short-term clinical evaluation of immediately restored maxillary TiOblast single-tooth implants. Int J Oral Maxillofac Implants 2004;19: 274-281.
43. Sclar AG. Strategies for management of single-tooth extraction sites in aesthetic implant therapy. $J$ Oral Maxillofac Surg 2004;62(9, Suppl. 2):90-105.

44. Vanden Bogaerde L, Rangert B, Wendelhag I. Immediate/early function of Brånemark System TiUnite implants in fresh extraction sockets in maxillae and posterior mandibles: An 18-month prospective clinical study. Clin Implant Dent Relat Res 2005;7(Suppl. 1): S121-S130.

45. Botticelli D, Renzi A, Lindhe J, Berglundh T. Implants in fresh extraction sockets: A prospective 5-year followup clinical study. Clin Oral Implants Res 2008;19: 1226-1232.

46. Galli F, Capelli M, Zuffetti F, Testori T, Esposito M. Immediate non-occlusal vs. early loading of dental implants in partially edentulous patients: A multicentre randomized clinical trial. Peri-implant bone and softtissue levels. Clin Oral Implants Res 2008;19:546-552.

47. Romeo E, Lops D, Rossi A, Storelli S, Rozza R, Chiapasco M. Surgical and prosthetic management of interproximal region with single-implant restorations: 1-year prospective study. J Periodontol 2008;79:10481055.

48. Cordaro L, Torsello F, Roccuzzo M. Clinical outcome of submerged vs. non-submerged implants placed in fresh extraction sockets. Clin Oral Implants Res 2009; 20:1307-1313.

49. Capelli M, Esposito M, Zuffetti F, Galli F, Del Fabbro M, Testroi T. A 5-year report from a multicentre randomised clinical trial: Immediate non-occlusal versus early loading of dental implants in partially edentulous patients. Eur J Oral Implantol 2010;3:209-219.

50. Valentini P, Abensur D, Albertini JF, Rocchesani M. Immediate provisionalization of single extraction-site implants in the esthetic zone: A clinical evaluation. Int $J$ Periodontics Restorative Dent 2010;30:41-51.

51. Suito H, Tomotake $Y$, Watanabe M, Nagao D, Ishida $Y$, Ichikawa T. Survival of immediate implant restoration: A retrospective study through 9-year-observation. $J$ Prosthodont Res 2011;55:141-145.

52. Spinato S, Agnini A, Chiesi M, Agnini AM, Wang HL. Comparison between graft and no-graft in an immediate placed and immediate nonfunctional loaded implant. Implant Dent 2012;21:97-103.

53. Schwartz-Arad D, Chaushu G. Immediate implant placement: A procedure without incisions. J Periodontol 1998;69:743-750.

54. Groisman M, Frossard WM, Ferreira HM, de Menezes Filho LM, Touati B. Single-tooth implants in the maxillary incisor region with immediate provisionalization: 2-year prospective study. Pract Proced Aesthet Dent 2003;15:115-122, 124; quiz 126.

55. Covani U, Crespi R, Cornelini R, Barone A. Immediate implants supporting single crown restoration: A 4-year prospective study. J Periodontol 2004;75:982-988.

56. Cornelini R, Cangini F, Covani U, Wilson TG Jr. Immediate restoration of implants placed into fresh extraction sockets for single-tooth replacement: A prospective clinical study. Int $J$ Periodontics Restorative Dent 2005;25:439-447

57. Barone A, Rispoli L, Vozza I, Quaranta A, Covani U. Immediate restoration of single implants placed immediately after tooth extraction. J Periodontol 2006;77: 1914-1920.

58. Lindeboom JA, Frenken JW, Dubois L, Frank M, Abbink I, Kroon FH. Immediate loading versus immediate provisionalization of maxillary single-tooth 
replacements: A prospective randomized study with BioComp implants. J Oral Maxillofac Surg 2006;64: 936-942.

59. Canullo L, Rasperini G. Preservation of peri-implant soft and hard tissues using platform switching of implants placed in immediate extraction sockets: A proof-of-concept study with 12- to 36-month followup. Int J Oral Maxillofac Implants 2007;22:995-1000.

60. Covani U, Marconcini S, Galassini G, Cornelini R, Santini S, Barone A. Connective tissue graft used as a biologic barrier to cover an immediate implant. $J$ Periodontol 2007;78:1644-1649.

61. Juodzbalys G, Wang HL. Soft and hard tissue assessment of immediate implant placement: A case series. Clin Oral Implants Res 2007;18:237-243.

62. Cornelini R, Barone A, Covani U. Connective tissue grafts in postextraction implants with immediate restoration: A prospective controlled clinical study. Pract Proced Aesthet Dent 2008;20:337-343.

63. Palattella P, Torsello F, Cordaro L. Two-year prospective clinical comparison of immediate replacement vs. immediate restoration of single tooth in the esthetic zone. Clin Oral Implants Res 2008;19:1148-1153.

64. Canullo L, Iurlaro G, Iannello G. Double-blind randomized controlled trial study on post-extraction immediately restored implants using the switching platform concept: Soft tissue response. Preliminary report. Clin Oral Implants Res 2009;20:414-420.

65. Redemagni M, Cremonesi S, Garlini G, Maiorana C. Soft tissue stability with immediate implants and concave abutments. Eur J Esthet Dent 2009;4:328337.

66. van Kesteren CJ, Schoolfield J, West J, Oates T. A prospective randomized clinical study of changes in soft tissue position following immediate and delayed implant placement. Int $J$ Oral Maxillofac Implants 2010;25:562-570.

67. Chung S, Rungcharassaeng K, Kan JY, Roe P, Lozada JL. Immediate single tooth replacement with subepithelial connective tissue graft using platform switching implants: A case series. J Oral Implantol 2011;37:559569.

68. Cosyn J, Eghbali A, De Bruyn H, Collys K, Cleymaet R, De Rouck T. Immediate single-tooth implants in the anterior maxilla: 3-year results of a case series on hard and soft tissue response and aesthetics. J Clin Periodontol 2011;38:746-753.

69. Pieri F, Aldini NN, Marchetti C, Corinaldesi G. Influence of implant-abutment interface design on bone and soft tissue levels around immediately placed and restored single-tooth implants: A randomized controlled clinical trial. Int J Oral Maxillofac Implants 2011;26:169-178.

70. Tsuda H, Rungcharassaeng K, Kan JY, Roe P, Lozada JL, Zimmerman G. Peri-implant tissue response following connective tissue and bone grafting in conjunction with immediate single-tooth replacement in the esthetic zone: A case series. Int J Oral Maxillofac Implants 2011;26:427-436.

71. Cabello G, Rioboo M, Fábrega JG. Immediate placement and restoration of implants in the aesthetic zone with a trimodal approach: Soft tissue alterations and its relation to gingival biotype. Clin Oral Implants Res 2013;24:1094-1100.

72. Lee YM, Kim DY, Kim JY, et al. Peri-implant soft tissue level secondary to a connective tissue graft in conjunction with immediate implant placement: A 2-year follow-up report of 11 consecutive cases. Int $J$ Periodontics Restorative Dent 2012;32:213-222.

73. Paul S, Held U. Immediate supracrestal implant placement with immediate temporization in the anterior dentition: A retrospective study of 31 implants in 26 patients with up to 5.5-years follow-up. Clin Oral Implants Res 2012;24:710-717.

74. Landis JR, Koch GG. The measurement of observer agreement for categorical data. Biometrics 1977;33: 159-174.

75. Vignoletti F, Discepoli N, Müller A, de Sanctis M, Muñoz $F$, Sanz M. Bone modelling at fresh extraction sockets: Immediate implant placement versus spontaneous healing: An experimental study in the beagle dog. $J$ Clin Periodontol 2012;39:91-97.

76. Koticha T, Fu JH, Chan HL, Wang HL. Influence of thread design on implant positioning in immediate implant placement. J Periodontol 2012;83:1420-1424.

77. Rungcharassaeng K, Kan JY, Yoshino S, Morimoto T, Zimmerman G. Immediate implant placement and provisionalization with and without a connective tissue graft: An analysis of facial gingival tissue thickness. Int $J$ Periodontics Restorative Dent 2012;32:657-663.

78. Al-Nsour MM, Chan HL, Wang HL. Effect of the platform-switching technique on preservation of periimplant marginal bone: A systematic review. Int J Oral Maxillofac Implants 2012;27:138-145.

79. Fickl S, Zuhr O, Wachtel H, Bolz W, Huerzeler M. Tissue alterations after tooth extraction with and without surgical trauma: A volumetric study in the beagle dog. J Clin Periodontol 2008;35:356-363.

80. Araújo MG, Lindhe J. Ridge alterations following tooth extraction with and without flap elevation: An experimental study in the dog. Clin Oral Implants Res 2009; 20:545-549.

81. Nevins $M$, Camelo $M$, De Paoli S, et al. A study of the fate of the buccal wall of extraction sockets of teeth with prominent roots. Int $J$ Periodontics Restorative Dent 2006;26:19-29.

82. Chan HL, Lin GH, Fu JH, Wang HL. Alterations in bone quality after socket preservation with grafting materials: A systematic review. Int J Oral Maxillofac Implants 2013;28:710-720.

83. Ten Heggeler JM, Slot DE, Van der Weijden GA. Effect of socket preservation therapies following tooth extraction in non-molar regions in humans: A systematic review. Clin Oral Implants Res 2011;22:779-788.

84. Chu SJ, Salama MA, Salama H, et al. The dual-zone therapeutic concept of managing immediate implant placement and provisional restoration in anterior extraction sockets. Compend Contin Educ Dent 2012;33: 524-532, 534.

85. Rompen E, Raepsaet N, Domken O, Touati B, Van Dooren E. Soft tissue stability at the facial aspect of gingivally converging abutments in the esthetic zone: A pilot clinical study. J Prosthet Dent 2007; 97(Suppl. 6):S119-S125.

86. Su H, Gonzalez-Martin O, Weisgold A, Lee E. Considerations of implant abutment and crown contour: Critical contour and subcritical contour. Int J Periodontics Restorative Dent 2010;30:335-343.

87. Tan PL, Dunne JT Jr. An esthetic comparison of a metal ceramic crown and cast metal abutment with an allceramic crown and zirconia abutment: A clinical report. J Prosthet Dent 2004;91:215-218.

88. Jung RE, Sailer I, Hämmerle CH, Attin T, Schmidlin P. In vitro color changes of soft tissues caused by 
restorative materials. Int $J$ Periodontics Restorative Dent 2007;27:251-257.

89. Sailer I, Zembic A, Jung RE, Hämmerle CH, Mattiola A. Single-tooth implant reconstructions: Esthetic factors influencing the decision between titanium and zirconia abutments in anterior regions. Eur J Esthet Dent 2007; 2:296-310.

90. van Brakel R, Noordmans HJ, Frenken J, de Roode R, de Wit GC, Cune MS. The effect of zirconia and titanium implant abutments on light reflection of the supporting soft tissues. Clin Oral Implants Res 2011;22:1172-1178.
91. Abrahamsson I, Berglundh T, Glantz PO, Lindhe J. The mucosal attachment at different abutments. An experimental study in dogs. J Clin Periodontol 1998;25:721 727.

Correspondence: Dr. Hsun-Liang Chan, 1011 North University Avenue, Ann Arbor, MI 48109-1078. E-mail: hlchan@umich.edu.

Submitted January 30, 2013; accepted for publication March 18, 2013. 